\title{
Coconut Husk and Processing Effects on Chemical and Physical Properties of Coconut Coir Dust
}

\author{
Sreenivas Konduru ${ }^{1}$ and Michael R. Evans ${ }^{2}$ \\ Department of Horticulture, Iowa State University, Ames, IA 50011 \\ Robert H. Stamps ${ }^{3}$ \\ Central Florida Research and Education Center, 2807 Binion Road, Apopka, \\ FL 32703
}

Additional index words. substrates, growing media, Cocos nucifera

\begin{abstract}
Chemical properties of unprocessed coconut (Cocos nucifera L.) husks varied significantly among 11 sources tested. The $\mathrm{pH}$ and electrical conductivities were significantly different among husk sources and ranged from 5.9 to 6.9 and 1.2 to $2.8 \mathrm{mS} \cdot \mathrm{cm}^{-1}$, respectively. The $\mathrm{NH}_{4}^{+}, \mathrm{NO}_{3}^{-}, \mathrm{Ca}$, and $\mathrm{Mg}$ levels did not differ significantly among husk sources and ranged from 0.2 to $1.8,0.2$ to $0.9,2.9$ to 7.3 , and nondetectable to $4.6 \mathrm{mg} \cdot \mathrm{kg}$ ${ }^{1}$, respectively. Levels of $\mathrm{P}, \mathrm{B}, \mathrm{Cu}, \mathrm{Fe}, \mathrm{Ni}, \mathrm{S}, \mathrm{Zn}, \mathrm{Mn}$, and Mo were all significantly different among husk sources and ranged from nondetectable levels to $33 \mathrm{ppm}$. The levels of $\mathrm{Na}, \mathrm{K}$, and Cl were significantly different among husk sources and ranged from 23 to 88,126 to 236, and 304 to 704 ppm, respectively. Coir dust (CD) produced by screening of wastegrade coir through 3-, 6-, or 13-mm mesh screens had significantly different fiber content, bulk densities, total solids, total pore space, air-filled pore space, water-filled pore space, and water-holding capacities as compared with nonscreened waste-grade coir. However, screen size did not significantly affect the physical properties of $\mathrm{CD}$. Neither compression pressure nor moisture level during compression of CD blocks significantly affected rehydration of compressed $\mathrm{CD}$ or physical properties of rehydrated $\mathrm{CD}$.
\end{abstract}

Artificial substrates are used extensively in the production of containerized greenhouse and nursery crops. Economics, availability of new materials, and environmental concerns relating to peat mining have stimulated interest in new substrate components. Most research into the development of new substrate components has focused on the use of municipal or agricultural wastes. Materials such as paper sludge (Chong and Cline, 1993; Tripepi et al., 1996), coal bottom ash (Butler and Bearce, 1995), shredded rubber (Evans and Harkess, 1997), kenaf (Wang, 1994), cotton waste (Wang, 1991), and composted yard waste (Beeson, 1996) have been proposed as sub-

Received for publication 16 Apr. 1998. Accepted for publication 31 July 1998. Journal Paper No. J17849 of the Iowa Agriculture and Home Economics Experiment Station, Ames, Project No. 3345, and supported by Hatch and State of Iowa Funds. Research conducted at Iowa State Univ., Ames. Use of trade names does not imply endorsement of the products named nor criticism of similar ones not named. This research was partially funded by the U.S. Agency for International Development through Chemonics International Consulting (Washington, D.C.) and the Agribusiness Systems Assistance Program (Manila, Philippines). The cost of publishing this paper was defrayed in part by the payment of page charges. Under postal regulations, this paper therefore must be hereby marked advertisement solely to indicate this fact.

${ }^{1}$ Graduate Research Assistant.

${ }^{2}$ Assistant Professor.

${ }^{3}$ Professor. strate components. However, some of these materials are not produced in large enough volumes to impact the market, and others are highly variable and may contain undesirable materials, such as glass, metal fragments, lead, and mercury.

Coconut coir dust (CD) has been proposed as an alternative substrate component. Evans et al. (1996) examined the chemical and physical properties of CD from numerous sources and reported that properties were generally within acceptable ranges except for electrical conductivity and chloride, which often exceeded recommended levels. Coir dust has also been demonstrated to be suitable for use in substrates through numerous production trials (Evans and Stamps, 1996; Lokesha et al., 1988; Meerow, 1995; Seeni and Latha, 1990; Stamps and Evans, 1997).

Coir dust is primarily produced in SriLanka, India, the Philippines, Indonesia, Mexico, Costa Rica, and Guyana. The Philippines reportedly is one of the largest producers of coconuts with $>427$ million trees (Barile and Sangalang, 1990). Sri Lanka produces $\approx 350,000$ to 500,000 tons of new CD annually (Hearth, 1993). With this level of production, large volumes of $\mathrm{CD}$ are potentially available to horticultural markets.

The raw material for the production of $\mathrm{CD}$ is the mesocarp tissue, or husk, of the coconut fruit. Husks may be soaked in water to soften them and facilitate grinding. After grinding of the husk, the long fibers are removed and used for various industrial purposes, such as rope and mat making. The remaining material, com- posed of pith tissue and short- and mediumlength fibers, is commonly referred to as wastegrade coir (WC). The WC may be screened to remove part or most of the fiber, and the remaining product is referred to as $\mathrm{CD}$. After screening, $\mathrm{CD}$ is allowed to dry to a specific moisture level and is then compressed into bales, wrapped, and shipped. The moisture level and compression pressures vary between producers.

In an earlier work (Evans et al., 1996), we reported significant differences in the physical and chemical properties of CD collected from different sources. However, we did not determine the factors contributing to this variability. The degree of variability observed in CD might have been due to the husk itself, or to the processing methods, namely, the screening and compressing of the $\mathrm{CD}$. In this research, our objectives were to determine the effects of the husk and processing methods on the physical and chemical properties of CD.

\section{Materials and Methods}

Coconut husk effect on chemical properties. Coconut husks were collected at 11 locations in the Philippines and Indonesia. Husks were collected directly from coconut plantations and had not been soaked in water or processed. The husks were ground in a hammer mill and screened to remove the long- and medium-length fibers. Mineral element concentration of the resulting CD samples was determined using the saturated media extract method as outlined by the North Central Regional Committee for Soil and Plant Analysis (Warncke, 1988). Electrical conductivity (EC; measured as $\mathrm{mS} \cdot \mathrm{cm}^{-1}$ ) was determined using a Beckman (Cedar Grove, N.J.) solubridge, and the $\mathrm{pH}$ was determined using an Orion (Cambridge, Mass.) $\mathrm{pH}$ meter. Nitrate nitrogen $\left(\mathrm{NO}_{3}^{-}\right.$ ) concentration was determined using the copperized cadmium reduction procedure (Keeney and Nelson, 1982) and ammonium $\left(\mathrm{NH}_{4}^{+}\right)$was determined by the nitroprussidesalicylate procedure (Wall et al., 1975). The Cl concentration was estimated by the mercury thiocyanate procedure (Fixen et al., 1988). For $\mathrm{P}, \mathrm{K}, \mathrm{Ca}, \mathrm{Mg}, \mathrm{B}, \mathrm{Fe}, \mathrm{Mn}, \mathrm{Zn}, \mathrm{Cu}$, and $\mathrm{Na}$, the filtered extract was used for simultaneous inductively coupled argon plasma emission spectrometry (Jones, 1977; Munter and Grande, 1981). Five replications were tested for each husk source. An analysis of variance (ANOVA) was conducted to determine if husk source significantly affected chemical properties. Where significance differences existed, a least significant difference (LSD) mean separation test $($ alpha $=0.05)$ was conducted to establish significant differences between means.

Screen size effect on physical properties. Waste-grade coir (WC) from the Philippines was screened through 3-, 6-, and 13-mmdiameter mesh rolling screens for $10 \mathrm{~min}$. Because of the different size openings in the screens, different amounts and sizes of fibers passed through. Fiber remaining in the screen was discarded and the $C D$ passing through the screens was collected for testing. The amount of pith and fiber in the resulting coir was 
determined by separating particles of $100-\mathrm{g}$ samples with a CSC Scientific (Fairfax, Va.) rotary shaker for $10 \mathrm{~min}$ using screen sizes of 8.0 and $6.3 \mathrm{~mm}$. Short fibers remaining in the coir were collected in these screens while pith tissue passed through. Bulk density (Bd), total solids (TS), total pore space (TPS), air-filled pore space (AFP), water-filled pore space (WFP), and water-holding capacity (WHC) of each of the screened CD products and the unscreened WC were determined using methods as described by Evans et al. (1996). Five replications were tested for each screened and unscreened material. An ANOVA and LSD mean separation test were conducted as previously described.

Compression effects on physical properties. Waste-grade coir from the Philippines was screened through a 13-mm-diameter mesh rolling screen for $10 \mathrm{~min}$ to remove the medium- and most of the short-length fibers. The resulting $\mathrm{CD}$ was compressed to form blocks using a steel cylinder $(30.5 \times 21.5 \times 11.5 \mathrm{~cm})$ and a Universal Testing Machine (SATEC Systems Inc., Grove City, Pa.). For each compression, $300 \mathrm{~g}\left(3060 \mathrm{~cm}^{3}\right)$ of the CD at moisture levels of $20 \%, 25 \%, 30 \%$, and $35 \%(\mathrm{w} / \mathrm{w})$ were placed into the cylinder and subjected to compression pressures of $70,88,106,141$, and $176 \mathrm{~kg} \cdot \mathrm{cm}^{-1}$. Pressures were maintained for $\approx 10 \mathrm{~s}$ and the blocks were removed. The CD blocks were rehydrated and air-dried to the original moisture level and the percentage of returned volume was measured. The physical properties of each of the resulting screened products and the unscreened WC were determined using methods previously described. Three replications were tested for each treatment. Multiple regression analysis was used to determine whether moisture and compression pressure had a significant effect on the returned volume and physical properties of $\mathrm{CD}$.

\section{Results and Discussion}

Coconut husk effect on chemical properties. Extract $\mathrm{pH}$ and electrical conductivity differed significantly among husk sources (Table 1). However, the $\mathrm{NH}_{4}^{+}, \mathrm{NO}_{3}^{-}, \mathrm{Ca}$, and $\mathrm{Mg}$ levels, which ranged from 0.2 to $1.8,0.2$ to $0.9,2.9$ to 7.3 , and nondetectable to 4.6 $\mathrm{mg} \cdot \mathrm{L}^{-1}$, respectively, did not differ significantly among husk sources (data not shown). Husks had significantly different levels of $\mathrm{P}$, $\mathrm{B}, \mathrm{Cu}, \mathrm{Fe}, \mathrm{Ni}, \mathrm{S}, \mathrm{Zn}, \mathrm{Mn}$, and Mo and ranged from nondetectable levels to $33 \mathrm{mg} \cdot \mathrm{L}^{-1}$ (data not shown). Some of the most significant differences in chemical composition between husk sources were for $\mathrm{Na}, \mathrm{K}$, and $\mathrm{Cl}$ (Table 1).

Previously, Evans et al. (1996) reported that CD from 12 sources contained significantly different levels of mineral elements. Some of the highest values and most significant variation were for $\mathrm{K}, \mathrm{Na}$, and $\mathrm{Cl}$. We speculated that the high levels and variability in the levels of these elements could be due to either the husks or the processing methods. In this study, we observed high levels and wide variation in these elements in unprocessed coconut husks.

Coconuts are thought to require salt appli- cation for optimal growth, and many growers apply salts, such as $\mathrm{NaCl}$ and $\mathrm{KCl}$, around coconut trees (Copeland, 1921; Menon and Pandalai, 1958). Coconuts are semi-halophytes and application of $\mathrm{NaCl}$ was shown to increase the $\mathrm{Na}$ and $\mathrm{Cl}$ content of the leaves (Remison et al., 1988). Baseden and Southern (1959) reported that the primary anion in coconut nut water was $\mathrm{Cl}^{-}$and that levels ranged from 1790 to $2146 \mathrm{mg} \cdot \mathrm{L}^{-1}$. Baseden and Southern (1959) were not able to correlate $\mathrm{Na}$ or $\mathrm{K}$ levels with proximity to the ocean. Thus, it is reasonable that the coconut fruit ion concentration, including the husk, may contain high levels of $\mathrm{Na}, \mathrm{K}$, and $\mathrm{Cl}$ and that these levels may vary depending upon factors such as fertilization practices.

Many CD producers and marketers have speculated that when high $\mathrm{Cl}, \mathrm{K}$, and $\mathrm{Na}$ levels occurred in $\mathrm{CD}$, it was due to the soaking of husks in saline water (personal communication). Although this practice could certainly contribute to high levels of these elements, it is clear from this study that the husk has a significant impact on chemical properties of $\mathrm{CD}$ and that management of soaking water will not necessarily eliminate these elements from CD.

Screen size effect on physical properties. While screening significantly reduced the amount of fiber, the amount remaining did not differ significantly among screen sizes (Table 2). Bulk density, TS, WFP, and WHC of WC were significantly lower and TPS and AFP were significantly higher than the same properties of screened CD (Table 2).

Thus, screening of WC significantly im-

Table 1. Chemical properties and concentrations of unprocessed coconut husks from different locations.

\begin{tabular}{|c|c|c|c|c|c|c|}
\hline \multicolumn{2}{|c|}{ Source } & \multirow[b]{2}{*}{$\mathrm{pH}$} & \multirow[b]{2}{*}{$\mathrm{EC}^{\mathrm{z}}$} & \multirow[b]{2}{*}{$\mathrm{K}^{\mathrm{y}}$} & \multirow[b]{2}{*}{$\mathrm{Na}^{y}$} & \multirow[b]{2}{*}{$\mathrm{Cl}^{\mathrm{y}}$} \\
\hline Country & City & & & & & \\
\hline \multirow[t]{9}{*}{ Philippines } & Davao City & 6.9 & 1.2 & 127 & 84 & 305 \\
\hline & Katitipan & 6.8 & 1.5 & 171 & 53 & 421 \\
\hline & Panakan & 6.3 & 2.2 & 220 & 75 & 647 \\
\hline & Panakan & 6.3 & 2.0 & 216 & 81 & 528 \\
\hline & Lajang & 5.9 & 1.6 & 195 & 23 & 420 \\
\hline & Kasilac & 6.7 & 1.7 & 218 & 35 & 423 \\
\hline & San Pablo City & 6.3 & 2.2 & 209 & 37 & 608 \\
\hline & Gis Gis & 5.9 & 2.8 & 204 & 89 & 744 \\
\hline & Tiaong & 6.2 & 2.0 & 236 & 27 & 514 \\
\hline \multirow[t]{2}{*}{ Indonesia } & Raiugkas Bitung & 6.0 & 1.6 & 213 & 58 & 423 \\
\hline & Lampung & 6.4 & 2.4 & 202 & 39 & 731 \\
\hline \multicolumn{2}{|c|}{ Significance of F } & $* * *$ & $*$ & $* * *$ & $* * *$ & $* * *$ \\
\hline \multicolumn{2}{|c|}{$\mathrm{LSD}_{0.05}$} & 0.5 & 0.7 & 33 & 29 & 206 \\
\hline
\end{tabular}

${ }^{2}$ Electrical conductivity (EC) reported as $\mathrm{mS} \cdot \mathrm{cm}^{-1}$.

${ }^{y}$ Value reported as $\mathrm{mg} \cdot \mathrm{L}^{-1}$ in saturated media extract.

${ }^{*}, * * *$ Significant at $P \leq 0.05$ and 0.001 , respectively.

Table 2. Effect of screen size on physical properties of coir dust.

\begin{tabular}{lccccccc}
\hline \hline $\begin{array}{l}\text { Screen size } \\
(\mathrm{mm})^{\mathrm{z}}\end{array}$ & $\begin{array}{c}\text { Fiber } \\
(\% \mathrm{w} / \mathrm{w})\end{array}$ & $\begin{array}{c}\text { Bulk } \\
\text { density } \\
\left(\mathrm{g} \cdot \mathrm{cm}^{-3}\right)\end{array}$ & $\begin{array}{c}\text { Total } \\
\text { solids } \\
(\% \mathrm{v} / \mathrm{v})\end{array}$ & $\begin{array}{c}\text { Total pore } \\
\text { space } \\
(\% \mathrm{v} / \mathrm{v})\end{array}$ & $\begin{array}{c}\text { Air-filled } \\
\text { pore space } \\
(\% \mathrm{v} / \mathrm{v})\end{array}$ & $\begin{array}{c}\text { Water-filled } \\
\text { pore space } \\
(\% \mathrm{v} / \mathrm{v})\end{array}$ & $\begin{array}{c}\text { Water-holding } \\
\text { capacity } \\
(\% \mathrm{w} / \mathrm{w})\end{array}$ \\
\hline Unscreened & 18 & 0.4 & 12 & 88 & 20 & 67 & 1241 \\
13 & 5 & 0.6 & 15 & 85 & 7 & 77 & 1382 \\
6 & 5 & 0.6 & 16 & 84 & 5 & 78 & 1396 \\
3 & 4 & 0.6 & 16 & 84 & 7 & 78 & 1357 \\
\hline $\begin{array}{l}\text { Significance } \\
\quad \text { of F }\end{array}$ & $* * *$ & $* * *$ & $* * *$ & $* * *$ & $* * *$ & $* * *$ & $* * *$ \\
LSD $_{0.05}$ & 6 & 0.01 & 2.9 & 2.9 & 4.0 & 2.8 & 43 \\
\hline
\end{tabular}

$\overline{{ }^{2} \text { Unscreened indicates waste grade coir and numbers indicate the diameter openings of the respective screen }}$ sizes.

${ }^{* * * *}$ Significant at $P \leq 0.001$. pacted the physical properties of the resulting CD. However, physical properties among screen sizes were not significantly different. It was visually apparent that fiber had little impact on properties until there was enough fiber to begin coalescing and forming mats or balls within the coir dust. Otherwise, the fiber simply packed down within the pith tissue and had act on physical properties.

ties. The percentage volume recovered after rehydration ranged from $78 \%$ to $91 \%$ (v/v) of the original volume and the $\mathrm{Bd}$ ranged from 0.06 to $0.07 \mathrm{~g} \cdot \mathrm{cm}^{-3}$ (data not shown). Neither of these properties were significantly affected Total pore space, AFP, WFP, TS, and WHC (data not shown) ranged from $78 \%$ to $91 \%, 6 \%$ to $10 \%, 71 \%$ to $76 \%, 18 \%$ to $22 \%$, and $850 \%$ to $1071 \%$, respectively, and these properties were not significantly affected by compression pressures or moisture level (data not shown).

Anecdotal reports and our own experience has shown that if coir is placed under too much it may fail to rehydrate and expand. compression in our study. The moisture levels and pressures used in the industry vary widely. However, based upon anecdotal reports, the in this study should sion. This contradiction may have occurred for several reasons. The first is that anecdotal reports concerning pressures and moistures used may not be accurate. Many coir produc- 
ers compress coir into bales based upon the ratio of initial to final volume. For example, many producers compress the $\mathrm{CD}$ so that the initial to the compressed volume is $6: 1$. In many cases, the exact compression pressures may not be known. Secondly, pressures were maintained for only $10 \mathrm{~s}$ in our study. Maintaining pressures for a longer time might have changed the results. Within the moisture, pressure, and time ranges used in this study, CD blocks were produced that rehydrated, expanded, and had acceptable physical properties for use as a substrate component.

\section{Literature Cited}

Barile, E. and J.B. Sangalang. 1990. Variation in sunlight reduction under canopy of different coconut cultivars and hybrid. Philippine Agriculturist 73(3 \& 4):287-295.

Baseden, S.C. and P.J. Southern. 1959. Evidence of potassium deficiency in coconut palms on coralderived soils in New Ireland from analysis of nut waters, husks, fronds and soils. Papua New Guinea Agr. J. 11:101-115.

Beeson, R.C., Jr. 1996. Composted yard waste as a component of container substrates. J. Environ. Hort. 14:115-121.

Butler, S.H. and B.C. Bearce. 1995. Greenhouse rose production in media containing coal bottom ash. J. Environ. Hort. 13:160-164.

Chong, C. and R.A. Cline. 1993. Response of four ornamental shrubs to container substrate amended with two sources of raw paper mill sludge. HortScience 28:807-809.

Copeland, E.B. 1921. The coconut. 2nd ed.
Macmillan, London.

Evans, M.R. and R.H. Stamps. 1996. Growth of bedding plants in Sphagnum peat and coir dustbased substrates. J. Environ. Hort. 14:187-190.

Evans, M.R. and R.L. Harkess. 1997. Growth of Pelargonium $\mathrm{x}$ hortorum and Euphorbia pulcherrima in rubber-containing substrates. HortScience 32:874-877.

Evans, M.R., S. Konduru, and R.H. Stamps. 1996. Source variation in physical and chemical properties of coconut coir dust. HortScience 31:965967.

Fixen, P.E., R.H. Gelderman, and J.L. Denning. 1988. Chloride tests, p. 26-28. In: W.C. Dahnke (ed.). Recommended chemical soil test procedures for the north central region. North Dakota Agr. Expt. Sta. Bul. 499.

Hearth, W. 1993. Coir dust as a growing medium. 7th Intl. Floriculture Symp. Colombo, Sri Lanka.

Jones, J.B., Jr. 1977. Elemental analysis of soil extracts and plant tissue ash by plasma emission spectroscopy. Commun. Soil Sci. Plant Anal. 8:345-365.

Keeney, D.R. and D.W. Nelson. 1982. NitrogenInorganic forms, p. 643-698. In: A.L. Page (ed.). Methods of soil analysis. part 2, 2nd ed. Amer. Soc. Agron., Madison, Wis.

Lokesha, R., D.M. Mahishi, and G. Shivashankar. 1988. Studies on use of coconut coir dust as a rooting media. Current Research, Univ. of Agricultural Sciences, Bangalore. 17(12):157-158.

Menon, K.P.V. and K.M. Pandalai. 1958. The coconut palm-A monograph. Indian Central Coconut Committee. Ernakulam, India.

Meerow, A.W. 1995. Growth of two tropical foliage plants using coir dust as a container medium amendment. HortTechnology 5:237-239.
Munter, R.C. and R.A. Grande. 1981. Plant tissue and soil extract analysis by ICP-atomic emission spectrometry, p. 653-672. In: R.M. Barnes (ed.). Developments in atomic plasma spectrochemical analysis. Heyden and Sons, London.

Remison, S.U., G.O. Iremiren, and G.O. Thomas. 1988. Effect of salinity on nutrient content of the leafs of coconut seedlings. Plant Soil 109:135138.

Seeni, S. and P.G. Latha. 1990. Post-transplantation growth of Phalaenopsis hybrid seedlings in community pots. J. Orchid Soc. India 4(1-2):127133.

Stamps, R.H. and M.R. Evans. 1997. Growth of Dieffenbachia maculata 'Camille' in growing media containing Sphagnum peat or coconut coir dust. HortScience 32:844-847.

Tripepi, R.R., M.W. George, A.G. Campbell, and B. Shafii. 1996. Evaluating pulp and paper sludge as a substitute for peat moss in container media. J. Environ. Hort. 14:91-96.

Wall, L.L., C.W. Gehrke, T.E. Neuner, R.D.Cathey, and P.R. Rexroad. 1975. Total protein nitrogen: Evaluation and comparison of four different methods. J. Assn. Offic. Anal. Chem. 58:811817.

Wang, Y. 1991. Evaluation of media consisting of a cotton waste for the production of tropical foliage species. J. Environ. Hort. 9:112-115.

Wang, Y. 1994. Using ground kenaf stem core as a major component of container media. J. Amer. Soc. Hort. Sci. 119:931-935.

Warncke, D. 1988. Recommended test procedure for greenhouse growth media, p. 34-37. In: W.C. Dahnke (ed.). Recommended chemical soil test procedures for the north central region. North Dakota Agr. Expt. Sta. Bul. 499. 